\title{
OUTSOURCING DOCUMENT MANAGEMENT SYSTEM/APPLICATION AS KEY FACTOR FOR COMPLIANT PROCESS IMPLEMENTATION AND INCREASING MANAGEMENT EFFICIENCY
}

\author{
Kristina Puksta ${ }^{1}$, Peteris Laurins ${ }^{2}$ \\ University of Latvia (Latvia)
}

\begin{abstract}
Today, in knowledge and information technology era, the world's businesses, both large and small, are increasingly seeking to use information technologies - especially information systems. There are implemented and maintained several of information systems: resource view based, customer orientated, document exchange information systems and universal ones, as opposed to specialized, and contains a lot more functionality offer. Information systems are implemented to ensure the core business functionality by automating certain processes, providing benefits such as business process transparency, arrangement and actualization. By the use of information systems certain services became popular, which are related with the established information system maintenance - the ongoing process of auditing, risk identification and management, and compliance regulations, laws, standards and guidelines. Such compliance is essential for the better functioning of information systems and aligns its activities. This article explores a theory of IT outsourcing and IT Compliance definition to give an idea of the need for it, and point to the benefits organizations can in carrying out these processes - system dynamics modeling research method was used in following research.

KEYWORDS: IT Compliance, Outsourcing, Business Efficiency, Electronic Documents Management Systems.
\end{abstract}

JEL CODE: M150

\section{Introduction}

In the world more and more information systems have been implemented. Information system users have become both the public and private sector representatives. To supply different processes or Organizations and institutions there have been used different types of information systems which are comprehensive, characterized by their universality. Organizations implementing information systems, expects and receives such benefits, which concerned to the organization processes and their alignment, automation, but little attention is paid to aspects such as information systems infrastructure, data security, system security, information systems for general compliance with the established standard-providing the process of incorporation in accordance with national and international regulations, guidelines and agreements. The reason of this poor awareness from business is occupation or simple reliance on information systems and its developers. The consequences of such negligence might negatively affect organization own information systems and core activities.

Current article will discuss the problems that show that the Non-IT service provider companies have a low IT Compliance in Their IT Infrastructure. The article purpose is to find the way for Organizations how to increase their business efficiency using IT Compliance.

\footnotetext{
Kristina Puksta - University of Latvia, Faculty of Economics and Management, Mg.sc.soc. Scientific interest: information technology, management.

E-mail:kpuksta@gmail.com

Tel.: +371 29862200 .

2 Peteris Laurins - University of Latvia, Faculty of Economics and Management, Mg.sc.soc. Scientific interest: information technology, management.

E-mail: djpeteris@gmail.com

Tel.: +3712654899.
} 
To achieve its goals authors have committed following tasks: a look at the IT outsourcing theories to provide a broader view of information systems implementation process deficiencies and benefits, see the IT Compliance fundamental concepts to give an idea of the need for it and use as well as a look at the IT Compliance at the nature of the practical examples - Outsourced EDMS, which will set standards and regulatory requirements relating to the EDMS adjustment measures. In conclusion section authors will find out the EDMS IT Compliance effect on business efficiency and for that system dynamics modeling method will be used. EDMS as the system was the object what was used to reach the goals of the research.

During the preparation of the article system dynamics modeling research method was used to capture the objects interconnection and impact between themselves. Foreign and Latvian scientists work were used for the research of its methodologies base. Scientific conferences and seminars, as well as the practical results were also used for research input.

\section{Review of existing IT outsourcing theories}

The outsourcing process is a complex structure consisting of numerous activities and sub-activities, carrying many managerial dilemmas and challenges. Many theories have been utilized to help the academic researchers to understand the nature of those activities, and to help practitioners successfully manage the process. It is a common knowledge that each phenomenon can be described by several frameworks that are embedded in various theoretical approaches. From its occurrence, the outsourcing has been approached by different theories. This creates confusion among the researchers of the outsourcing phenomenon. Authors Perunovic and Pedersen on 2007 had collected and identified significant number of theories that could explain the outsourcing phenomenon (Perunovic, Pedersen, 2007).

Authors have found previous researches where Perunovic and Pedersen on 2007 have done literature study in outsourcing theories from the 1990 up to 2006. Table below shows their papers and the theories utilized.

The last column indicates phases of the outsourcing process the paper and its theoretical grounding have addressed. The abbreviations P, VS, T, MR, and R stand for the phases of the outsourcing process i.e., Preparation, Vendor(s) Selection, Transition, Managing relationship, and Reconsideration.

Table 1. Theories utilized in the research of the outsourcing process

\begin{tabular}{|c|c|c|c|c|c|}
\hline Year & Authors & Theory & Method & Key points & $\begin{array}{l}\text { Applicability to } \\
\text { outsourcing } \\
\text { process }\end{array}$ \\
\hline 1995 & $\begin{array}{l}\text { Lacity and } \\
\text { Willoocks }\end{array}$ & $\begin{array}{l}\text { Transaction Costs } \\
\text { Economics (TCE) }\end{array}$ & Case study & $\begin{array}{l}\text { Experiences to the TCE } \\
\text { framework of efficient governance } \\
\text { structures resulted in anomalies }\end{array}$ & P. VS, MR, R \\
\hline 1995 & $\begin{array}{l}\text { Pinnington } \\
\text { and } \\
\text { Woolcock }\end{array}$ & Core competences & Case study & $\begin{array}{l}\text { Growth of IT vendor industry is } \\
\text { creating a new firm relationship for } \\
\text { the IS function }\end{array}$ & $P, R$ \\
\hline 1995 & $\begin{array}{l}\text { Willoocks and } \\
\text { Choi }\end{array}$ & Relational view & Case study & $\begin{array}{l}\text { Defining characteristics of total IT } \\
\text { outsourcing strategic alliances and } \\
\text { identifying problems of managing } \\
\text { them }\end{array}$ & P.MR \\
\hline 1985 & $\begin{array}{l}\text { Willoocks et } \\
\text { al. }\end{array}$ & Core competences & $\begin{array}{l}\text { Conceptual } \\
\text { framework }\end{array}$ & $\begin{array}{l}\text { Factors around which IT } \\
\text { outsourcing decisions can be } \\
\text { based }\end{array}$ & $P$ \\
\hline 1996 & Aubert et al. & $\begin{array}{l}\text { TCE, Incomplete } \\
\text { contract theory }\end{array}$ & Case study & $\begin{array}{l}\text { TCE and Incomplete contract } \\
\text { theory support the choice of } \\
\text { activity to be outsourced and } \\
\text { contract management between the } \\
\text { outsorucer and its vendor }\end{array}$ & P.MR \\
\hline 1996 & Ulset & $\begin{array}{l}\text { TCE, Property rights } \\
\text { theory }\end{array}$ & Survey & $\begin{array}{l}\text { When substantial externalities are } \\
\text { involved, like in the supply of R\&D, } \\
\text { TCE should be combined with } \\
\text { property rights theory to explain } \\
\text { the use of governance } \\
\text { mechanisms }\end{array}$ & P. VS, MR \\
\hline
\end{tabular}




\begin{tabular}{|c|c|c|c|c|c|}
\hline Year & Authors & Theory & Method & Key points & $\begin{array}{l}\text { Applicability to } \\
\text { outsourcing } \\
\text { process }\end{array}$ \\
\hline 1997 & Brandes et al. & $\begin{array}{l}\text { TCE, } \\
\text { competences }\end{array}$ & Case study & $\begin{array}{l}\text { Outcomes are more successful if } \\
\text { outsourcing decision is based on } \\
\text { core competence and cost } \\
\text { efficiency and if outsourced unit is } \\
\text { able to develop strong resource } \\
\text { base }\end{array}$ & P. MR, R \\
\hline 1999 & $\begin{array}{l}\text { Vining and } \\
\text { Globerman }\end{array}$ & TCE & $\begin{array}{l}\text { Conceptual } \\
\text { framework }\end{array}$ & $\begin{array}{l}\text { Framework for making the } \\
\text { outsourcing decision }\end{array}$ & $P$ \\
\hline 2000 & Amold & $\begin{array}{l}\text { TCE, } \\
\text { competences }\end{array}$ & $\begin{array}{l}\text { Conceptual } \\
\text { framework }\end{array}$ & $\begin{array}{l}\text { Framework for making the } \\
\text { outsourcing decision }\end{array}$ & $P$ \\
\hline 2000 & $\begin{array}{l}\text { Baden-Fuller } \\
\text { et al. }\end{array}$ & Core competences & $\begin{array}{l}\text { Conceptual } \\
\text { framework }\end{array}$ & $\begin{array}{l}\text { Framework for making the } \\
\text { outsourcing decision }\end{array}$ & $P$ \\
\hline 2001 & Lee & $\begin{array}{l}\text { Knowledge-based view, } \\
\text { Core competences }\end{array}$ & Survey & $\begin{array}{l}\text { Knowledge sharing is positively } \\
\text { related to outsourcing success }\end{array}$ & MR \\
\hline 2001 & Mahnke & Evolutionary economics & $\begin{array}{l}\text { Conceptual } \\
\text { paper }\end{array}$ & $\begin{array}{l}\text { Propositions regarding scope, } \\
\text { speed and switching costs have } \\
\text { been developed }\end{array}$ & P. T, MR, R \\
\hline 2001 & $\begin{array}{l}\text { Roy and } \\
\text { Aubert }\end{array}$ & RBV & Case study & $\begin{array}{l}\text { The best predictor of success and } \\
\text { failure is the governance mode } \\
\text { and the position of project in the } \\
\text { value matrix }\end{array}$ & $P$ \\
\hline 2001 & Zviran et al. & Relational view & Case study & $\begin{array}{l}\text { Factors determining success from } \\
\text { outsourcer's and vendor's } \\
\text { perspective - good project } \\
\text { definition and specifications, good } \\
\begin{array}{l}\text { project management, } \\
\text { trustworthiness, } \\
\text { competence }\end{array} \\
\text { technical }\end{array}$ & P, VS, T, MR, R \\
\hline 2003 & Barthélemy & $\begin{array}{l}\text { Agency theory. } \\
\text { Relational view }\end{array}$ & Case study & $\begin{array}{l}\text { Managing outsourcing by } \\
\text { contracts and trust }\end{array}$ & MR \\
\hline 2004 & Aubert et al. & $\begin{array}{l}\text { TCE, Incomplete } \\
\text { contract theory }\end{array}$ & Survey & $\begin{array}{l}\text { Uncertainty is major deterrent to } \\
\text { outsourcing. while the level of } \\
\text { technical skills is the most }\end{array}$ & $P$ \\
\hline 2005 & $\begin{array}{l}\text { Barthélemy } \\
\text { and Geyer }\end{array}$ & TCE & Survey & $\begin{array}{l}\text { Determinants of outsourcing and } \\
\text { quasi-outsourcing decisions }\end{array}$ & $P$ \\
\hline 2005 & $\begin{array}{l}\text { Gottschalk } \\
\text { and Solli- } \\
\text { Sæether }\end{array}$ & 11 theories & Case study & $\begin{array}{l}\text { Core competences and } \\
\text { stakeholder theory explain best } \\
\text { critical success factors }\end{array}$ & P, MR, R \\
\hline 2005 & $\begin{array}{l}\text { Pati and } \\
\text { Desai }\end{array}$ & Core competences & $\begin{array}{l}\text { Conceptual } \\
\text { framework }\end{array}$ & $\begin{array}{l}\text { Framework for making the } \\
\text { outsourcing decision }\end{array}$ & $P$ \\
\hline 2006 & $\begin{array}{l}\text { Barthélemy } \\
\text { and Quelin }\end{array}$ & $\begin{array}{l}\text { TCE, Resource-based } \\
\text { view }\end{array}$ & Survey & $\begin{array}{l}\text { To restrict vendor's opportunism, } \\
\text { contracts must contain incentives } \\
\text { and penalties, as well as pricing } \\
\text { and monitoring clauses }\end{array}$ & P, VS, MR, R \\
\hline 2006 & $\begin{array}{l}\text { Gottschalk } \\
\text { and Solli- } \\
\text { Sæther }\end{array}$ & $\begin{array}{l}\text { Cumulative theory, } \\
\text { TCE, Agency. } \\
\text { Contracts, RBV, Core } \\
\text { competences, } \\
\text { Relational view, Social } \\
\text { exchange }\end{array}$ & $\begin{array}{l}\text { Conceptual } \\
\text { model }\end{array}$ & $\begin{array}{l}\text { Maturity mode| of IT outsourcing } \\
\text { relationships }\end{array}$ & P, VS, T, MR, R \\
\hline 2006 & $\begin{array}{l}\text { Halldórsson } \\
\text { and Skjøtt- } \\
\text { Larsen }\end{array}$ & $\begin{array}{ll}\text { TCE, Agency } & \text { theory. } \\
\text { Contract } & \text { theory. } \\
\text { Relational view } & \\
\end{array}$ & Case study & $\begin{array}{l}\text { Challenges TCE, agency, and } \\
\text { contract theories and argues for } \\
\text { relational view }\end{array}$ & P. VS, T, MR \\
\hline 2006 & $\begin{array}{l}\text { Miranda and } \\
\text { Kim }\end{array}$ & TCE, Institutional theory & Survey & $\begin{array}{l}\text { The logic of TCE decision maker is } \\
\text { contingent on institutional context }\end{array}$ & $P$ \\
\hline 2006 & Mirani & Evolutionary economics & $\begin{array}{l}\text { Conceptual } \\
\text { framework }\end{array}$ & $\begin{array}{l}\begin{array}{l}\text { Stages of relationships are } \\
\text { contracts, } \\
\text { hierarchies }\end{array} \\
\text { networks }\end{array}$ & MR \\
\hline 2006 & $\begin{array}{l}\text { Whitten and } \\
\text { Wakefield }\end{array}$ & $\begin{array}{l}\text { TCE, Social-exchange } \\
\text { theory }\end{array}$ & Survey & $\begin{array}{l}\text { A second-order switching costs } \\
\text { model for specifying switching } \\
\text { behaviour }\end{array}$ & $\mathrm{R}$ \\
\hline
\end{tabular}

Source: Perunović, Pedersen, 2007. Outsourcing Process and Theories

Reviewing the table it is obvious that almost all of the theories from 1990 till 2006 are applicable for preparation phase. But in this survey authors didn't found any IT Compliance or Due Diligence topic related theory what caused a reason to look deeper in this case. Authors have selected four most challenging theories for broader view what was done mostly by Perunovic and Pedersen on 2007. 


\subsection{Transaction Cost Economics}

Transaction cost economics (TCE) has been the most utilized theory of outsourcing. TCE is perceived to provide the best decision making tools to help organizations to decide to outsource and to prepare themselves for forthcoming outsourcing arrangements. The governance features of the theory influenced that it has been applied in studying the Managing relationship phase, whilst the concept of switching costs made the theory applicable in the reconsideration phase. Another useful issue for outsourcing provided by TCE is explanation of contractual complexity. Though TCE has not been utilized explicitly for studying the Vendor selection phase, its sub-theory (if we may say so), the theory of incomplete contracting, has been applied in studying the structure and contents of outsourcing contracts, and related preparation and contract management activities. Even though it has been exercised extensively in outsourcing applications, the TCE has several indulgencies. Lacity and Willcocks (1995) found that the original mapping to the TCE framework only explained few IT sourcing decisions and generated much more anomalies in their sample. Another critique could be that TCE relies on a single transaction as a unit of analysis, neglecting the contemporary industrial collaborative arrangements. Finally, TCE is static, which doesn't correspond to dynamism of current business environment (Perunović, Pedersen, 2007).

So despite of the fact that this theory is used for Preparation, Vendors Selection, Managing relationship, and Reconsideration it is too wide and the to concrete at the same time what could cause anomalies as researchers describe it before. No IT Compliance or Due Diligence has been included.

\subsection{Relational View}

Relational view develops and explains how firms gain and sustain competitive advantage within inter-organizational relationships. Its key premise - the concept of relational rents has been explored to explain how firms choose their future outsourcing partners and preferred type of the relationship. It has been also utilized in studying the Transition, Managing relationship and Reconsideration phases. This makes the relational view to be the only theory that has been applied in the research of all the outsourcing process' phases (Perunović, Pedersen, 2007).

Here authors see the risk that this theory has almost one of the highest risks to avoid any IT Compliance review before outsourcing as in different countries due to cultural environment inter-organizational relationship are more close then expected where any DUE Diligence process could be done quite formal.

\subsection{Resource-based View}

The core premise of the resource-based view is that resources and capabilities can vary significantly across firms, and that these differences can be stable. If resources and capabilities of a firm are mixed and deployed in a proper way they can create competitive advantage for the firm. The resource-based view in outsourcing builds from a proposition that an organization that lacks valuable, rare, inimitable and organized resources and capabilities, shall seek for an external provider in order to overcome that weakness. Therefore the most prominent use of the theory is in the Preparation phase of the outsourcing process for defining the decision making framework and in the vendor selection phase for selecting an appropriate vendor. The theory has been also used to explain some of the key issues of the Managing relationship and Reconsideration phases (Perunović, Pedersen, 2007).

It is essential during preparation phase to do risk assessment if the labor resource cut-off is the only reason to do outsourcing. It is proved that in companies who's core business is not connected to provide IT services, IT infrastructure is not compliant.

\subsection{Knowledge-based View}

The knowledge-based view provides insight in understanding how individuals co-operate to produce goods and services. The knowledge-based view distinguishes two ways how knowledge is shared among 
partners. They are knowledge generation and knowledge application. The knowledge-based view has been used in utilized in the outsourcing research to prove that knowledge sharing in the Managing relationship phase is positively related to the success of an outsourcing arrangement (Perunović, Pedersen, 2007).

It should be checked how the knowledge is documented, do the company has intellectual knowledge repository or any other documented evidence what could make easier take-over during the Transition. If this is not included in the contract to do so, then in practice there could be dispute about it.

\subsection{IT Compliance challenge in companies}

IT compliance in organizations and companies had always been a challenge. For example - those companies, who are IT services, are not their core business mostly has problems with their IT infrastructure compliance with data security and IT management best practices - like ITIL. Those companies, who start to outsource their IT infrastructure, are usually surprised how non-compliance their IT infrastructure has been before. Usually there are lack of proper technical documentation and processes, who describe how the IT infrastructure should be managed and what to do in critical situations. Usually these gaps have been found too lately when Outsourcing Company has started to take over responsibility. Such an activity like Due Diligence has not always performed, what is usually caused by saving finances and that always affects outsourcing transition and transformation process. On the next sections step to be more compliant in IT will be described - example will be observed of electronic document management system (EDMS) implementation.

\section{Electronic Document Management Systems (EDMS) as a IT outsourcing product}

Currently a lot of organizations has found reasonable to improve their IT infrastructure implementing EDMS. Its purpose is to supply exchange electronically documents internally in the organization and externally. EDMS has been widely used in such organizations where document flow is significant or its core business requires usage such a system: for example - automatic invoice creation and sending, fast invoice receive and payment, document approval etc. - all what happens with documents daily. Areas where EDMS are used most often are connected with consumer retail, cargo, logistics, accounting service and IT infrastructure services or maintenance, where applicable electronically documents are produced and approved.

Today world's practice show, that EDMS mostly are used in following organizations:

- Huge enterprises, where amount of employees are above 250, who provides qualitative and effective exchange of electronically documents between all employees and business partners/public sector organizations.

- Small and (10-49 employees) and medium companies (50-249), if their profile is dependent from operational and qualitative document exchange process. Necessity for EDMS is higher if organization's branches are located in different locations. In these cases electronically document exchange happens only thru EDMS.

EDMS has been used to supply following processes, but not limited to:

- electronic document process supply on digital environment according its lifecycle phases: creation, registration, update, version management, copying, delegation, execution, coordination, distribution and archiving;

- document movement automatisation (receiving documents, linking and sending);

- searching for documents on digital environment;

- document circulation process controls implementation;

- security measures (ContentManager.eu.com, 2011).

Organizations who have decided to use the EDMS must meet the following criteria: the current movement is a complex document, the document in a process of at least 3 members, the company's job more than 
10 units and the company has regional branches (Puksta, Laurins, 2012: 3). Only when at least half of the above criteria have been met, implementation of EDMS is useful for organization. On IT market there exists in several EDMS systems - specialized in providing enterprise-specific business processes and multi-purpose, designed for small businesses, because the document provides basic life tasks. It is important that prior to the adoption of EDMS implementation, the organization accomplish a business process analysis. The EDMS benefit and lack determination should be the analysis task.

$\mathrm{CCH}$ Australian Company who is engaged in various business areas of research, in 2009 made benefit analysis of the use of EDMS. Replies to the questions were received from the companies where EDMS is used every day and those who were planning to use it. After the survey: $72.8 \%$ of respondents claimed that the company increased efficiency and productivity, better organization of the process sequence $-69.1 \%$, improving risk management $-65.6 \%, 56.3 \%$ of respondents noticed a decrease in document maintenance and storage costs (Moore, 2009). Respondents who plan to implement EDMS, according results of surveys, mostly expect: improvement of the organizational process sequence, the risk management improvements, the company's efficiency and productivity increases, Figure 1 (Moore, 2009).

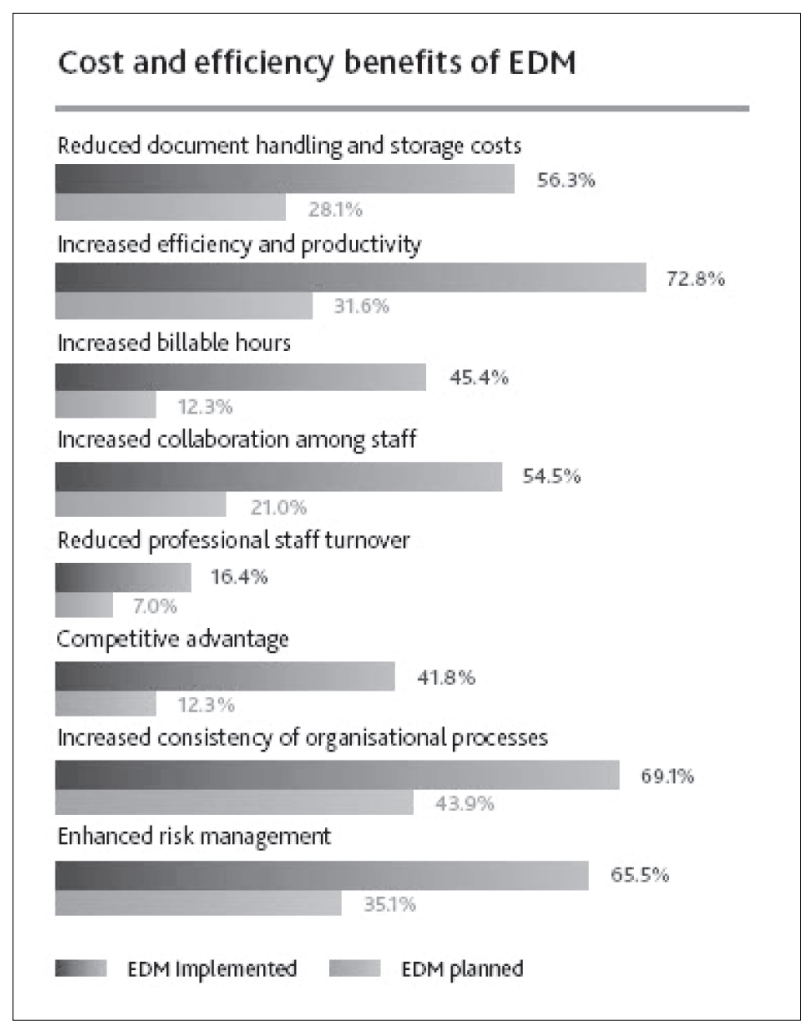

Figure 1. Professionals and Electronic Document Management Systems

Source: Moore, 2009.

An entrepreneur in today's market is offered several options for EDMS purchase and one of them EDMS as outsourced solution (Outsourcing Document Management System). EDMS as outsource solution provides to organizations opportunity to hire a team of IT professionals engaged in EDMS customization, implementation and maintenance activities (Phillips, Andrews, 2003). Outsourcing offer, for example, following benefit-driven effect: the company does not increase the number of employees, the company focused solely on primary activities. Contractor has the option to choose to buy a ready-made EDMS that is versatile, but cheaper, or to invest more and to order EDMS, which will be adapted for his needs. Organization shall in any case have to deal with employees' investment in training to work with the new system. 
By studying the outsourcing situation in Latvia, it can be concluded that the main problem is uncertainty about the customer experience. EDMS, as a content management solution has been offered by the Latvian companies such as: SIA "Hortus Digital", LLC "DPA" Ltd. and "AstonBaltic" and also the foreign companies, such as: FileNet, Documentum, OpenText, Identitech, Hummingbird (Phillips, Andrews, 2003).

\section{EDMS and IT compliance impact on business efficiency at company}

As a result of implemented outsourced service EDMS is viewed from the perspective of IT Compliance. Outsourcers, renting EDMS, have to make analysis in order to establish an information system functioning regulatory and standards set, and perform EDMS compliance or verification audit. An audit helps to identify risks at least in the EDMS-related areas: data security, user authorization and access rights, the activities (record deletion, modification or addition) record, process life-cycle structure, managed content (documents according to their types, forms and documents blanks) compliance with regulatory laws and standards. IT Compliance can be classified into the following groups:

- legislation relating to the general processes of information systems: data security, user logins and access rights, and the operation records (Wright, 2008: 116);

- implementation of procedures or regulations relating to the company's business processes: Business Process Integration Information System in accordance with procedures or rules;

- standards or regulations relating to information systems managed by the content: documents, templates, forms, electronic signature, copyright;

- The authors found the following International Organization for Standardization standards relating to the EDMS and its managed content:

- $\quad$ ISO 2709 Information and documentation - Format for information Exchange;

- $\quad$ ISO 15489 Information and documentation - Records management;

- ISO 21127 Information and documentation - A reference ontology for the interchange of cultural heritage information;

- $\quad$ ISO 23950 Information and documentation - Information retrieval (Z39.50) - Application service definition and protocol specification;

- $\quad$ ISO 10244 Document management - Business process base lining and analysis;

- $\quad$ ISO 32000 Document management - Portable document format.

The above standards are international, but they should be limited to national-level regulatory and standards, as well as the company's internal regulations, manuals and specifications for information systems subordinate to them (Ademero, 2012).

In Latvian situation, they are: Latvian national legislation relating to information systems development and maintenance of electronic documents, electronic signature, the Latvian national standards, as well as each company, according to specific, internal procedures and agreements.

IT Compliance according to the Latvian state law provides the EDMS general subordinate. Is defined as, for example, EDMS can cooperate with other public sector information systems or archiving documents may be applied to EDMS archiving process. In this way, are standardized and adapted to the functioning of the EDMS.

Latvian national standards can set various types of conditions for developing documents and EDMS section may affect the preparation of its documents or forms design. Blanks and / or forms development takes place once, according to existing regulations, and shall be amended only if it is approved by regulatory changes. The following blanks or forms in the information system users to resolve time-consuming regulatory law studies at the moment is to develop a document in which the work piece is maintained in the information system.

The company's internal rules or an agreement defining the soft EDMS business procedures of the way that is minimally different from the processes that take place in real life. This process integration guarantees that users will be able to quickly retrain to the new EDMS and daily work tasks will have much better quality. 
Although today, Latvian IT Compliance is not much performed and often used in practice, it is increasingly realized in foreign companies. By studying the experience of foreign companies, it is clarified that the IT Compliance contributes to the company's operating actualization by solving the following tasks: reduces administrative costs, are listed in the company's basic processes, arranged in the utilization of resources, is possible to make functioning resources monitoring, check information systems what is organized according to international regulations, reduces the data theft and unauthorized access risk, and logs/checks EDMS end user's activities.

Using system dynamics modeling research method, the authors have portrayed the impact of IT Compliance at the company, which was introduced and arranged with EDMS, see Figure 2. Greatest benefits of IT Compliance are considered to be the EDMS general arrangement that results in a reduced system of data theft or hacking risk. In case of risk execution, the company's competitiveness would be destroyed and hence its ability to compete with other organizations/competitors would be reduced. Another consequence of the EDMS system functions arranging is the return of the investment in EDMS, which allows organizations increase confidence that the implemented solutions are useful. Of course this statement is valid if the company's core business is dependent to a large volume document processing. Any increase in utilization of EDMS follows with increase of higher company's business process performance, which is closer to reality. This business process integration in EDMS encourages system end user better adoption, therefore, would increase usage of the system and the results of their quality. If the quality of data increases, then the use of risk will be reduced, which means that the data used for processing and analysis will provide the advantage of the opportunity to take timely and correct decisions. In meanwhile - correctness of the decision depends on the company's business process better execution. Chart was completed when the results of EDMS users will increase and IT Compliance requirement to perform a reduction executes.

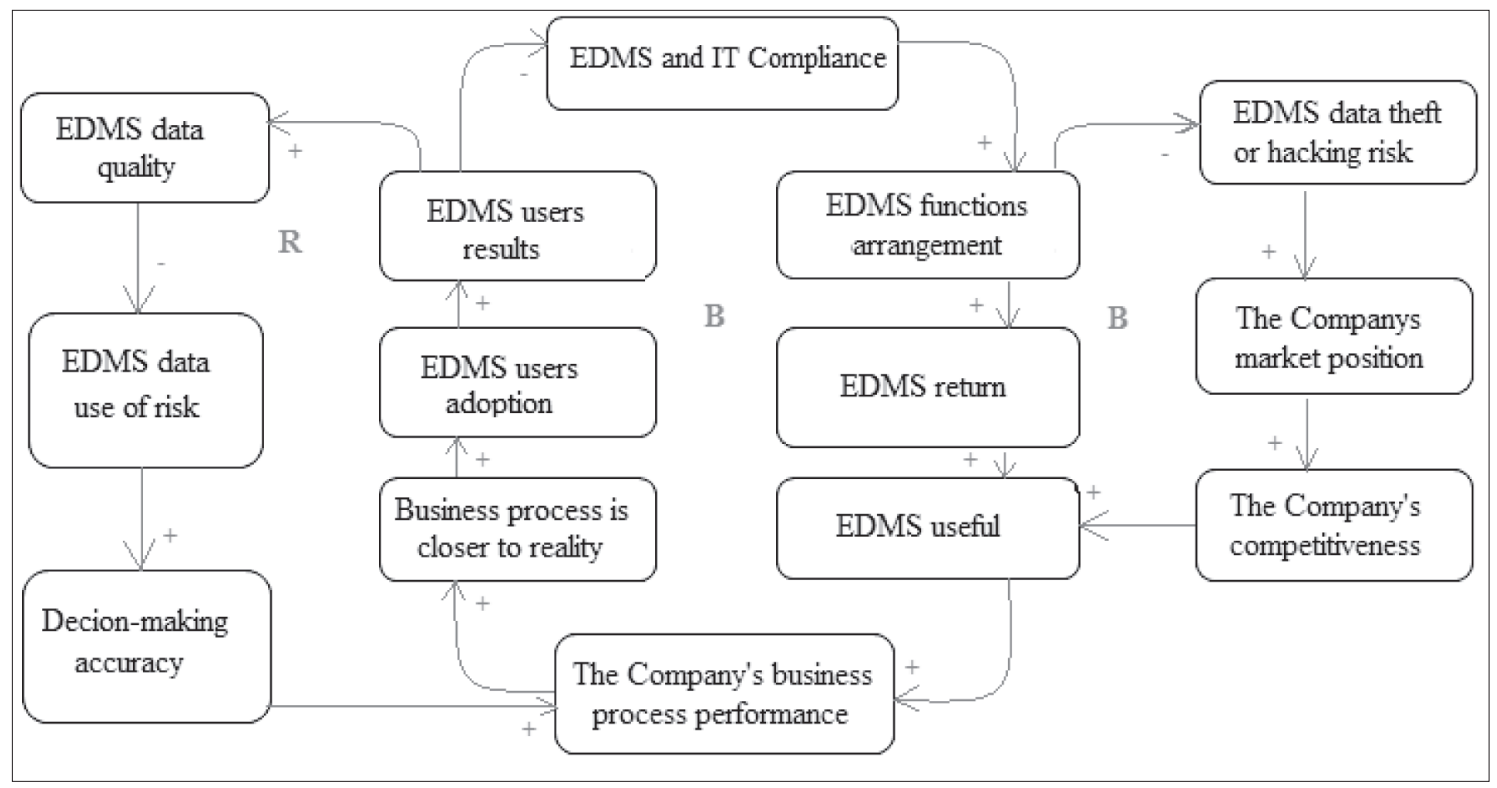

Figure 2. System Dynamic Diagram of EDMS and IT compliance Impact on a Business Efficiency

Source: Puksta, 2012.

\section{Conclusions}

Although today the IT Compliance in Latvia has not been much observed, the authors can clearly say that it is necessary and it has a role in the business. The authors, using system dynamics modeling techniques have shown the importance of IT Compliance at enhancing the efficiency of the company. For most business 
benefit from IT Compliance performance of existing information systems in accordance with the existing arrangement: the international and national regulations, standards, the company's internal policies, agreements, and specific actions - procedures. Such a readjustment of the most common activities are reached: general functioning arrangement of the information system, business process customization to practical work, content managed with existing regulations, which generally brings corporate business processes to increase output. Aligning the functioning of the system obtains improvement of the safety system to reduce data theft or the risk of tearing. Not everybody in the world is immune to hacker attacks, and particular occurrence of the risk bears any loss of business. One of the worst scenarios would be loss of market position and competitiveness reduction, as a competitor take over and use theft data for their own benefit.

Organizations who want to make more compliant their IT infrastructure could be not only large or medium-sized enterprises but also small companies, since the implementation of information systems no longer require large investments in IT technology development, as well as IT staff maintenance. Currently on the market there are available following solutions such as: information systems or outsourced cloud computing products and software as a service. Solutions are available for rent and pay only for the use of - charge calculation methodology of the "Pay-as-you-go", which includes the cost of maintenance. Using these solutions, the operators had planned to promote the development of information technology to execute the plans for cost save. For the development of the company must take care that in turn provides long-lasting market position. For the state that would mean the opportunity to grow and increase everyone's standard of living, which already has the benefit that every citizen can feel personally. The more businesses companies invest in their development, the more likely it will be to live well.

\section{References}

Ademero, Inc. (2012). 12 Things to Know About Document Compliance. Ademero. Website: http://www.ademero.com/ document-management/12-things-to-know-about-document-compliance_article, visited on 30.05.2012.

Computhink, Inc Corporate Headquarters. (2012). Are You Compliant? The Legal Need for Document Management. Computhink website: http://www.computhink.com/about-us/compliancy/ [26.04.2012].

ContentManager.eu.com. (2011). Benefits of a Document Management System. ContentManager.eu.com website: http:// www.contentmanager.eu.com/dmsbens.htm [26.04.2012].

DeLuccia IV, J. J. (2008). IT Compliance and Controls: Best Practices for Implementation. New Jersey: Wiley.

Moore, L. (2009). Professionals and Electronic Document Management - EDM delivers value beyond expectations. CCH website: http://www.cchatter.com.au/?p=114 [26.04.2012].

Perunović, Z., Pedersen, J. L. (2007). Outsourcing Process and Theories. Dallas: POMS 18th Annual Conference, p. 8-13.

Phillips, J., Andrews, L. (2003). Outsourced Document Management: Is it the Solution for Your Organization? Digital Publishing Solutions: http://www.dpsmagazine.com/content/ContentCT.asp?P=98 [26.04.2012].

Puksta, K., Laurins, P. (2012). Management Information System's Usage and Topicality at Small and Medium Enteprise Segment. Riga: School of Business Administration Turiba.

Wright, C. S. (2008). The IT Regulatory and Standards Compliance Handbook: How to Survive Information Systems Audit and Assessment. Burlington: Syngress. 
DOKUMENTU VALDYMO SISTEMA / PROGRAMA, KAIP ESMINIS SUDERINTO PROCESO VYKSMO IR VALDYMO EFEKTYVUMO DIDINIMO VEIKSNYS

Kristina Puksta, Peteris Laurins

Latvijos universitetas (Latvija)

Santrauka

Šiandien, žinių ir informacinių technologijų eroje, pasaulio verslas (tiek didelis, tiek mažas) vis labiau siekia išnaudoti informacines technologijas, ypač informacines sistemas. Šiuo metu taikoma keletas informacinių sistemų: paremtos ištekliais, orientuotos į klientus, dokumentų apsikeitimo sistemos ir universalios sistemos, lemiančios daug didesni funkcionalumą. Informacinès sistemos diegiamos siekiant verslo funkcionalumo automatizuojant tam tikrus procesus, tai suteikia verslo procesams skaidrumo, tvarkos ir palengvina jų igyvendinimą. Taikant informacines sistemas, populiarėja paslaugos, susijusios su informacinių sistemų palaikymu - nuolatinis auditas, rizikos nustatymas ir valdymas, suderinamumo reguliavimas, taisyklès, standartai bei gairès. Toks suderinamumas yra būtinas, siekiant veiksmingo informacinių sistemų funkcionavimo. Šiame straipsnyje nagrinejjama IT teorija ir IT suderinamumo samprata, išryškinama šių procesų taikymo organizacijose nauda. Darbe taikytas sistemų dinamikos modeliavimo metodas.

PAGRINDINIAI ŽODŽIAI: IT suderinamumas, iškèlimas, verslo efektyvumas, elektroninès dokumentu valdymo sistemos.

JEL KODAS: M150 